\title{
Successful transplant of mesenchymal stem cells in induced osteonecrosis of the ovine femoral head. Preliminary results ${ }^{1}$
}

\author{
Sucesso no transplante de células tronco mesenquimais em ovinos com osteonecrose induzida \\ da cabeça do fêmur. Resultados preliminares
}

\author{
Matheus Levi Tajra Feitosa ${ }^{\mathrm{I}}$, Leandro Fadel ${ }^{\mathrm{II}}$, Patrícia Cristina Baleeiro Beltrão-Braga ${ }^{\mathrm{III}}$, Cristiane Valverde Wenceslau ${ }^{\mathrm{IV}}$, Irina \\ Kerkis $^{\mathrm{V}}$, Alexandre Kerkis ${ }^{\mathrm{VI}}$, Eduardo Harry Birgel Júnior ${ }^{\mathrm{VII}}$, João Flávio Panattoni Martins ${ }^{\mathrm{VIII}}$, Daniele dos Santos Martins ${ }^{\mathrm{IX}}$, \\ Maria Angélica Miglino ${ }^{\mathrm{X}}$, Carlos Eduardo Ambrósio ${ }^{\mathrm{IX}}$
}

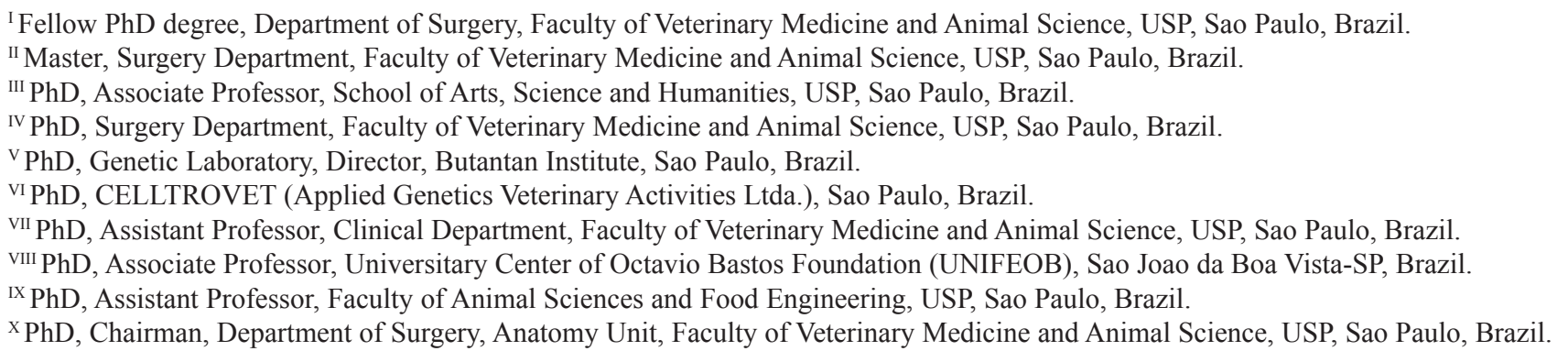

\begin{abstract}
Purpose: Evaluate the bone tissue recovery following transplantation of ovine mesenchymal stem cells (MSC) from bone marrow and human immature dental-pulp stem cells (hIDPSC) in ovine model of induced osteonecrosis of femoral head (ONFH). Methods: Eight sheep were divided in three experimental groups. First group was composed by four animals with ONFH induced by ethanol through central decompression (CD), for control group without any treatment. The second and third group were compose by two animals, six weeks after ONFH induction received transplantation of heterologous ovine MSC (CD + oMSC), and hIDPSC (CD + hIDPSC), respectively. In both experiments the cells were transplanted without application of any type of immunosupression protocol. Results: Our data indicate that both cell types used in experiments were able to proliferate within injured site providing bone tissue recovery. The histological results obtained from CD+hIDPSC suggested that the bone regeneration in such animals was better than that observed in CD animals. Conclusion: Mesenchymal stem cell transplant in induced ovine osteonecrosis of femoral head by central decompression technique is safe, and apparently favors bone regeneration of damaged tissues.
\end{abstract}

Key words: Hip Joint. Stem Cells. Femur Head. Sheep.

\section{RESUMO}

Objetivo: Verificar os efeitos das células-tronco mesenquimais da medula óssea de ovinos e da polpa dentária imatura humana em ovinos com osteonecrose induzida, da cabeça do fêmur. Métodos: Oito ovelhas foram distribuídas em três grupos experimentais. O primeiro grupo foi composto por quatro animais com osteonecrose da cabeça do fêmur induzida por etanol através da descompressão central, que não receberam nenhum tratamento. O segundo e o terceiro grupo, cada um composto por dois animais, receberam transplante heterólogo de células tronco mesenquimais de ovinos e polpa dentária imatura humana seis semanas após a indução da osteonecrose da cabeça do fêmur, respectivamente. Em ambos os grupos experimentais as células foram transplantadas sem o uso de drogas imunossupressoras. Resultados: Os achados demonstram que as células-tronco mesenquimais injetadas na cabeça do fêmur se encontravam viáveis após o transplante no novo sítio e proliferaram em pouco tempo. Os dados histológicos sugerem que a regeneração óssea nos animais transplantados com polpa dentária imatura humana foi mais rápida do que nos animais submetidos somente a descompressão central. Conclusão: O transplante de células tronco mesenquimais na osteonecrose da cabeça do fêmur induzida em ovinos através da técnica de descompressão central é um procedimento seguro, e aparentemente favorece a regeneração óssea de tecidos lesados.

Descritores: Articulação do Quadril. Células-Tronco. Cabeça do Fêmur. Ovinos.

${ }^{1}$ Research performed at Post-graduate Program of Anatomy in Domestic and Wild Animals, Department of Veterinary Surgery, Faculty of Veterinary Medicine and Animal Science, Sao Paulo University (USP), Brazil. There were a collaborative work among Butantan Institute and CELLTROVET, a Brazilian company of stem cell supply and UNIFEOB, where made preclinical trials with ovine. 


\section{Introduction}

Osteonecrosis of the femoral head (ONFH) is a progressive degenerative disease that leads to the total collapse of the femoral head and that requires an excisional arthroplasty for the replacement of the coxofemural articulation. Because preservation of the articulation is a desired goal, conservative procedures are used for treating the initial stages of $\mathrm{ONFH}^{1}$. $\mathrm{ONFH}$ is a multifactorial disease for which the pathogeny is still unknown. Some of the known risk factors of developing ONFH are abusive consumption of alcohol and prolonged use of steroids in patients with immune-mediated disease ${ }^{2}$.

Among the treatment choices to preserve articulation are central decompression, central decompression associated to vascularized and non-vascularized bone graft, autologous transplant of bone-marrow stem cells, and extracorporeal shockwave treatment ${ }^{2-5}$.

Several models have been used to create the human disease, with the aim of testing therapeutic approaches able to preserve the coxofemural articulation. Most of these models have been based on the vascular suppression theory in which the disease may be induced either surgically or through overdoses of steroid drugs ${ }^{6}$.

However, ovines are excellent animal model for translational medicine because the body scores close to humans and as production animal, a suitable specie for housekeeping and management ${ }^{7-10}$.

Treatment choices suggested so far show viable results only when applied at the subclinical stages of the disease. As for the experimental models, these lead to the total collapse of the femoral head, leaving no options other than its replacement ${ }^{2-6,11}$.

The ovine model suggested by Manggold ${ }^{12}$ shows characteristics similar to those found at the early stages of osteonecrosis in human, in which the articular cartilage is kept intact, the internal trabecular structure is preserved, and macrocirculation is maintained. The anatomic dimensions of the model are similar to those of humans, making it a useful experimental model for developing therapies for ONFH.

Mesenchymal stem cells (MSC) can be easily isolated from bone marrow and expanded in vitro. Currently these cells are the best studied, when compare with stem cells from other sources from adult tissues. Their therapeutic potential has been demonstrated previously in multiple studies ${ }^{13}$.

The dental pulp of deciduous teeth is another, and recent, alternative for obtaining MSC. Recent works suggest that these cells carry a great potential to be used in tissue reconstruction and especially in orthopedics once they are of easy access (isolation from dental pulp), efficient extraction, great capacity to differentiate, and good affinity with biomaterials ${ }^{14}$.

Studies done in patients with ONFH have shown that the level of activity and the number of mesenchymal cells inside the stromal and hematopoietic compartments of the bone marrow are depressed in these patients ${ }^{15}$. These findings have indicated that mesenchymal bone cells can be used on necrotic injuries of the femoral head ${ }^{16}$.
Although cell therapy for ONFH in humans has produced satisfactory results ${ }^{17}$, in transplanted patients who are evaluated years later different levels of transplant effectiveness are observed. It is still not known how many cells survive after the transplant or how they may in fact contribute to the regenerative process ${ }^{18}$.

Among the different techniques that have been proposed to track the fate of implanted cells in vivo, methods involving transduction of detectable genetic markers, such as those encoding for B-galactosyltransferase (LacZ) and green fluorescent protein gene (GFP), are the only ones that allow stable and reliable long-term tracking of transplanted cells ${ }^{19}$.

In the present study we applied cellular therapy using MSC from ovine bone marrow and human immature dental-pulp stem cells (hIDPSC) in ovines with ONFH induced by intra-bone injections of ethanol. We used light microscopy to evaluate the response obtained to the applied central decompression technique and tracked the ovine bone-marrow stem cell through the LacZ reporter gene.

\section{Methods}

\section{Experimental design}

This study was approved by the bioethics committee of the Faculty of Veterinary Medicine and Animal Science, Sao Paulo University. Eight clinically healthy sheep weighing on average $35 \mathrm{~kg}$ and averaging one year of age were used in this study.

The animals were divided in three experimental groups. First group was composed by four animals with ONFH induced by ethanol through central decompression (CD), which did not receive any treatment. The second group e third group, each was compose by two animals, six weeks after $\mathrm{ONFH}$ induction received transplantation of heterologous ovine MSC (CD+MSC), and hIDPSC (CD+hIDPSC), respectively. All the animals of second and third group were euthanized 10 weeks after induction of injury for evaluation. While the animals from CD group these, two were euthanatized 6 and 10 weeks after induction of injury to confirm the success in reproducing the disease in the animal model. The femoral head of the right limb (Health limb) of each animal was used as control for the treatment done in the left limb of that animal (ONFH Induced Limb).

\section{Anesthesia and post-surgical procedures}

After 24 hours of food fasting and 12 of not drinking water, animals were pre-medicated with midazolam maleate $(0.6 \mathrm{mg} / \mathrm{kg})$ and meperidine hydrochloride $(2 \mathrm{mg} / \mathrm{kg})$ intravenously (IV). Anesthesia was induced by propophol $(3 \mathrm{mg} / \mathrm{kg})$ associated to fentanyl hydrochloride $(2.5 \mu \mathrm{g} / \mathrm{kg})$ and maintained with isoflurorane. Post-surgical analgesia was provided with $1 \mathrm{mg} / \mathrm{kg}$ of flunixin meglumine and $25 \mathrm{mg} / \mathrm{kg}$ of sodium dipyrone IV and maintained with $2 \mathrm{mg} / \mathrm{kg}$ of tramadol twice a day until animals were euthanized. Antibacterial prophylaxis was obtained with penicillin $40000 \mathrm{UI} / \mathrm{kg}$ for 10 days. 

pulp hIDPSC

Culturing and isolating ovine bone-marrow MSC and

The 15 and $30 \mathrm{ml}$ of bone marrow were collect of the iliac crest using $5 \mathrm{ml}$ syringes and a $14 \mathrm{G}$ bone marrow biopsy needle $\left(\right.$ Biomedical $\left.{ }^{\circledR}\right)$. The aspirate bone marrow of the ovine was filtrated in a $100 \mu \mathrm{m}$ mesh and diluted in PBS at 1:3. Next, the solution was homogenized and added in to ficoll (Ficoll, Histopaque ${ }^{\circledR}$ ). The solution was centrifuged at $2000 \mathrm{RPM}$ for $30 \mathrm{~min}$ at $20^{\circ} \mathrm{C}$. The resulting pellet was resuspended in PBS and centrifuged at 1000 RPM. The procedure was repeated three times. The pellet was then resuspended in alpha minimum essential medium (alpha-MEM) and plated in $25 \mathrm{~cm}^{2}$ flasks at initial density of $2.0 \times 10^{5} / \mathrm{cm}^{2}$. The medium was supplemented with 15\% fetal bovine serum (Invitrogen Corporation) and $1 \%$ total solution of antibiotics $(100 \mathrm{U} / \mathrm{ml}$ of penicillin and $100 \mu \mathrm{g} / \mathrm{ml}$ of streptomycin). Cells were incubated in a Thermo Electron Corporation incubator (Forma Series 11 Water Jacketed $\mathrm{CO}_{2}$ Incubator HEPA Class 100) under culturing conditions of $37^{\circ} \mathrm{C}$, relative humidity of approximately $100 \%$, and $5 \% \mathrm{CO}_{2}$. After 5 days, no adherent cells derived BM were removed, and the medium was replaced. At $70 \%$ confluence, cells were harvested with $0.25 \%$ triple (Sigma, St. Louis, Mo., USA GIBCO) for 5 minutes at $37^{\circ} \mathrm{C}$ and were replaced in $25-\mathrm{cm}^{2}$ and $75 \mathrm{~cm}$ flasks (Corning, New York, N.Y., USA). Images of incubated cells were visualized in an inverted microscopy (NIKON Eclipse-TS 100), with lenses of 4x, 10x, 20x, and 40x and kept with a capture system (MTC Digital Color Camera).

The hIDPSC have been isolated and extensively characterized ${ }^{20-24}$. They were cultured before transplantation following protocol described in Kerkis et al. ${ }^{20}$.

\section{Core decompression}

To take the radiologic images we used the ventro-dorsal projection with a Konex 30x40, film AGFA $^{\circledR}$ frame. The apparatus used was Emic ${ }^{\circledR}$ with Toshiba ampoule, $500 \mathrm{~mA}$ and $150 \mathrm{Kv}$. The technique applied was $300 \mathrm{~mA}, 80 \mathrm{Kv}$ at $0.08 \mathrm{~s}$. For the central decompression technique we accessed the greater trochanter through an incision in the skin with a scalpel 14 and divulsion of the subcutaneous tissue. The superficial gluteus muscle suffered an incision in the direction of its muscle fibers, as well as the femoral biceps muscle, which was retracted with the help of a Weitlaner self-retaining retractor.

After confirmation of the visualization of the greater trochanter, a Kirschnner thread was introduced at $1 \mathrm{~mm}$ from the greater trochanter to the center of the femoral head. For the greater trochanter to be correctly aligned with the femoral head of the animal it was necessary that a helper stretched and twisted the animal's member medially so the thread could be easily introduced and reach the center of the femoral head. Once the right radiographic position for the thread was confirmed, the $3.5 \mathrm{~mm}$ cannula drill was introduced up to the femoral head, the thread was removed, and a new radiographic image was taken to determine the correct position of the drill in the center of the femoral head, and $10 \mathrm{ml}$ of absolute ethanol were administrated. When the procedure was over, the drill was removed, the created hole was filled with bone wax (Johnson \& Johnson), the muscles were brought together using a simple continuous Vycril ${ }^{\circledR}$ 2-0 suture, and the skin was brought together using a simple interrupted Nylon 2-0 suture. This procedure was done both for inducing the injury and for the cellular therapy with bone-marrow MSC of the ovines and hIDPSC (Figure 1).
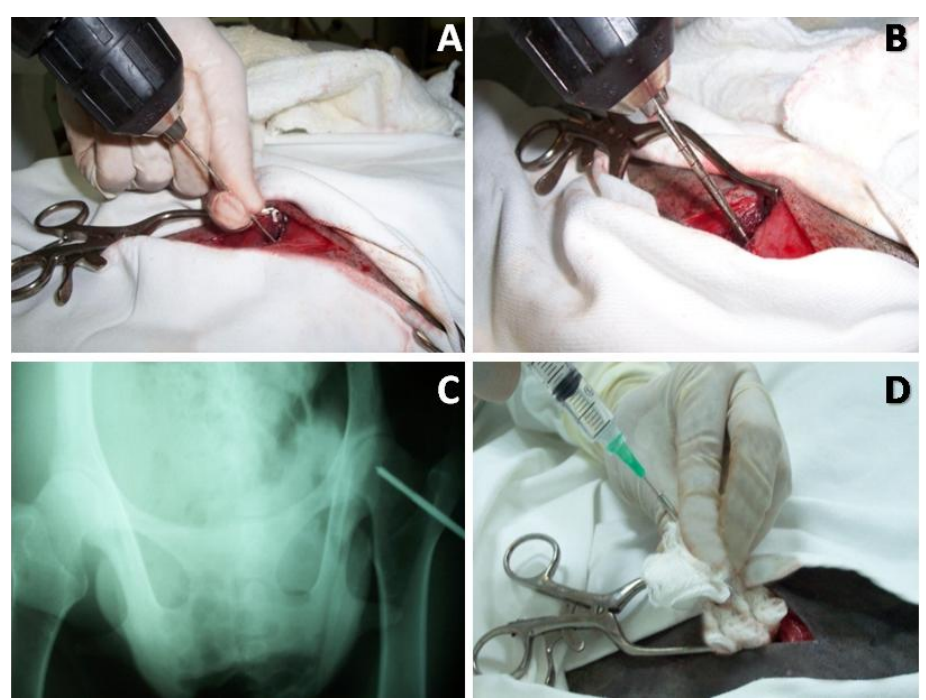

FIGURE 1 - Central decompression technique of the femoral head with injections of absolute ethanol. A. Passage of the $1 \mathrm{~mm}$ Kirschnner from the greater trochanter to the center of the femoral head. B. Passage of the $3.5 \mathrm{~mm}$ cannula drill through the great trochanter to the center of the femoral head. C. Radiographic image of the correct position of the cannula drill. D. Injection of absolute ethanol into the center of the femoral head.

\section{Viral transduction of ovine bone-marrow stem cells}

Exogenous genes were transfected to the ovine bone-marrow MSC through the $\mathrm{pLNPoZ}$ retroviral vector created from the MoMLV (Moloney Murine Leukemia Virus) retrovirus. The retroviral vector used has the bacterial LacZ gene under control of the UTR region of the poliovirus, which is the viral promotor LTR (L) of the retrovirus that regulates the gene expression of the neomycin phosphotransferase gene $(\mathrm{N})$. Infections of the bone marrow were done according to a 5-day protocol with 24-hour intervals between each step of the process, as described below.

On the first day, the clones of the amphotropic packaging cells PT67/LNPoZ, NIH3T3 cells, and the oBMSC of the second or third passages were seeded in tissue culture plates of $60 \mathrm{~mm}$ diameter and density of $1 \times 10^{6}$ for the virus-producing cells and $5 \times 10^{5}$ for stem cells, in $4 \mathrm{ml}$ of alpha-MEM. On the second day, the culture medium was aspirated and replaced. On the third day, the viral infection was performed. The supernatant of culture of clones containing the PT67 virus-producing cells was carefully homogenized, collected, and centrifuged at 10000 RPM per $1 \mathrm{~min}$ at room temperature. The culture medium of the stem cells was once again replaced, this time by a medium containing $8 \mu \mathrm{g} / \mathrm{ml}$ of Polybrene. We used $1 \mathrm{ml}$ of viral suspension to infect each plate containing stem cells. On the fourth day, the culture medium was aspirated and replaced by a new one. NIH3T3 cells were used as positive control for the infection. 
Expression analysis of the exogenous genes (LacZ) in mesenchymal stem cells previously transduced

We seeded $1 \times 10^{6}$ cells in $60 \mathrm{~mm}$ plates and incubated them with X-Gal solution (X-gal $1 \mathrm{mg} / \mathrm{ml}_{1}, \mathrm{~K}_{4} \mathrm{Fe}(\mathrm{CN})_{6} 5 \mathrm{mM}$, $\mathrm{K}_{3} \mathrm{Fe}(\mathrm{CN})_{6} 5 \mathrm{mM}$ e $\left.\mathrm{MgCl}_{2} 1 \mathrm{mM}\right) 24$ hours later to check the expression of the $B-G a l$ in the ovine bone-marrow stem cells transduced with the $\mathrm{pLNPoZ}$ vector. The incubation protocol with $\mathrm{X}-\mathrm{Gal}$ is described as follows: the medium culture was removed and $0.5 \%$ glutaraldehyde solution was added over cells for 15 minutes at room temperature for fixation. The solution was then removed and the cells washed 3 times with PBS every 5 minutes. The X-Gal solution was added to the cells and then incubated at $37^{\circ} \mathrm{C}$ for 1 to 6 hours. Stained cells were observed with phase-contrast microscopy. The same protocol was used for observation of $\beta-G a l$ expression in the femoral head from animals after euthanasia. The result of procedures for introduce LacZ in oMSC renamed these cells as LacZ-oMSC.

\section{Preparation of oBMSCs and hIDPSCs to be transplanted}

The cell cultures were trypsinized and centrifuged at $21^{\circ} \mathrm{C}$ at $1000 \mathrm{rpm}$ for $7 \mathrm{~min}$. Pelleted cells were resuspended with PBS and centrifuged under the same conditions. PBS washing was done twice to remove any remaining Fetal Bovine Serum (FBS). After cell counting, $1 \times 10^{6}$ LacZ-oMSCs and $1 \times 10^{6}$ hIDPSCs were resuspended in $500-1000 \mu \mathrm{l}$ of saline solution and inoculated in the animals.

\section{Evaluation by light microscopy}

Animals were euthanized with overdoses of sodium thiopental 2.5\%; the femoral heads were then collected and immersed for 48 hours in formalin 10\%. Specimens of the left and right femoral heads of control and test animals were evaluated. The femoral head was sectioned at the femoral column in 4 slices parallel to the center of the femoral head. The material was submitted to decalcification with formic acid $10 \%$, inserted in paraffin, and stained with hematoxylin and eosin.

\section{Results}

In all animals submitted to the $\mathrm{CD}$ technique, regardless of receiving stem cell therapy, it was possible to observe hemorrhagic injuries in the region where the drill was applied and a clearer circular area at the femoral head was observed, characterizing the collapsing of the bone usually found on the femoral heads of humans with ONFH. The same was not macroscopically observed in a region of bone necrosis in the femoral heads of controls (Figure 2).

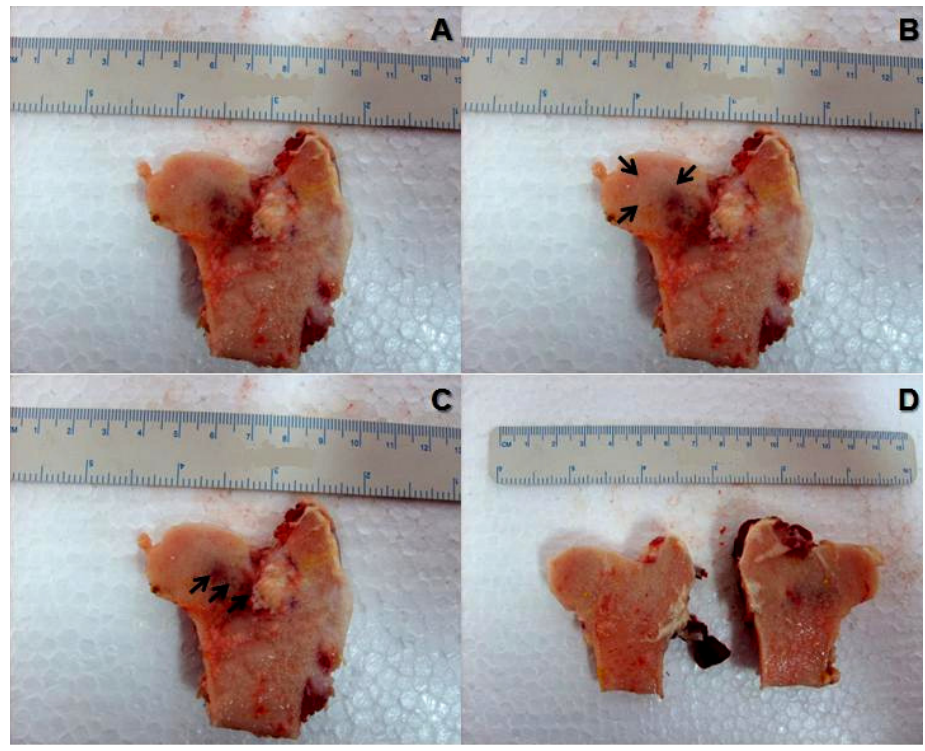

FIGURE 2 - Macroscopic aspects of femoral head and column of ovine submitted to osteonecrosis of the femoral head and stem cell therapy. A. Image of the femoral head of a sheep submitted to induction of osteonecrosis of the femoral head (ONFH). B. The arrows delineate the area of bone collapse visible in (A). C. The arrows point to the passage of the cannula drill, from the great trochanter to the center of the femoral head. D. Femoral head of the contralateral member of the same animal.

The oMSCs cultivated in this experiment were effectively transduced with the LacZ reporter gene expressing the $B-G a l$ (Figure 3).

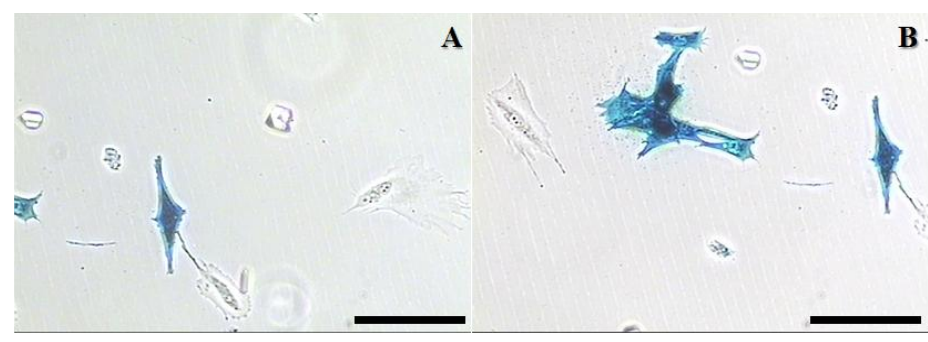

FIGURE 3 - Representative figures of expression of ß-Gal (blue) by LacZ gene reporter observed in the bone-marrow stem cells of ovines (A,B). Scale bar: A, B $=100 \mu \mathrm{m}$.

After transplant can be identification of the LacZ-oMSCs cells in the center of the femoral head proliferated by expression gene $\beta$-Gal (blue), performed X-gal stained. This result indicates the success of the transplant technique and as well engraftment of MSC cells. We used samples of the femoral head of test samples and of controls to search for the presence of the Lac $\mathrm{Z}$ reporter gene (Figure 4). 
Samples of femoral head (CD- group) were processed according to the same protocol used for the expression analysis of MSC in vitro.

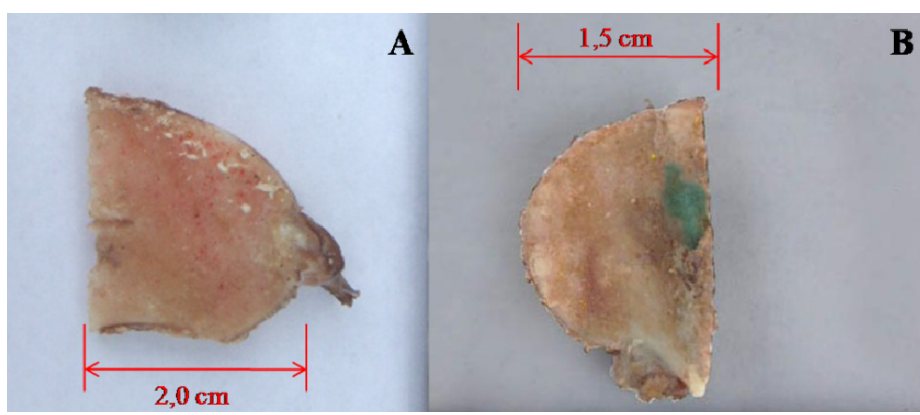

FIGURE 4 - Representative figure of expression of the reporter gene LacZ is evidenced by $\beta-G a l$ staining in the femoral head of ovines. A. Ovine femoral head control (Health limb). B. Experimental expressing LacZ.

Slices were prepared for histological analysis from the $\mathrm{CD}$ group, from the $\mathrm{CD}+\mathrm{hIDPSC}$ group and from the control group (Health Limb). The trabecular portion of the femoral head of the $\mathrm{CD}$ group, which did not receive cell transplantation, (left - experimental) was filled after 6 weeks with live bone marrow and rich in mesenchymal cells and osteoblasts, demonstrating the process of bone tissue repairing usually occurring in young animals, which suffer injury in this region, apparent decrease of the space composed by compact bone was observed. Furthermore, on higher magnification the presence of bone marrow precursor cells was visualized, suggesting their further differentiation and new bone tissue formation. These findings indicate that the bone was in its initial process of bone tissue regeneration. Slices from $\mathrm{CD}+\mathrm{oBMSC}$ were not obtained due to failures in processing the material for histological analysis. Apparently, the trabecular bone was better organized in the $\mathrm{CD}+\mathrm{hIDPSC}$ group than in the $\mathrm{CD}$ group and was similar to that found in controls. Evaluation of the femoral head of the CD+hIDPSC group showed the remnants of the bone marrow in the live trabecular bone proximal to the cartilage, although in smaller amounts than found in the $\mathrm{CD}$ group. Our data suggest that use of hIDPSC make contribution to better regeneration process as compared with $\mathrm{CD}$ group. Since, slices from $\mathrm{CD}+\mathrm{oBMSC}$ were not obtained due to failures in processing the material for histological analysis impeding such comparison (Figure 5).

Our preliminary histological studies showed a good bone tissue recovery in animals, which received hIDPSC. However, we cannot confirm, that benefits observed in CD-hIDPSC group are, in fact, exclusively due to hIDPSC transplantation.

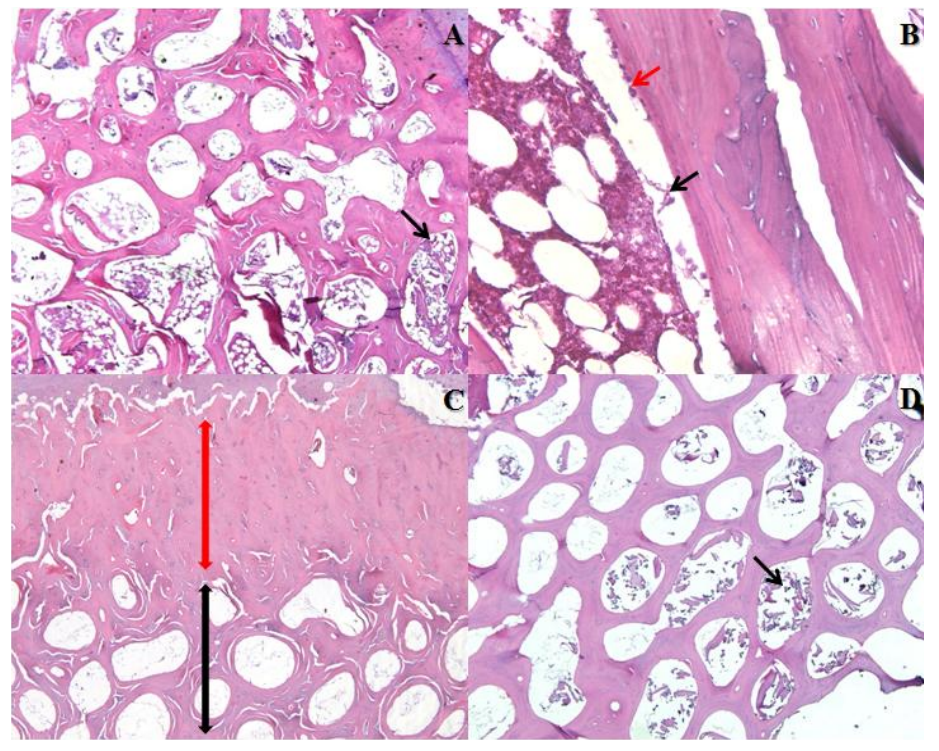

FIGURE 5 - Photomicrographies of the femoral head of ovines submitted to induction of osteonecrosis of the femoral head with ethanol and heterologous transplant of of mesenchymal bone-marrow cells from different sources. A. Arrow indicates presence of live bone marrow in the bone trabeculae. B. Zoom-in of the region shown in (A); black arrow points to cell of mesenchymal origin, red arrow to osteoblasts. C. Red arrow delineates region of the compact lamellar bone and black arrow the trabecular bone region in the control animal. D. Trabecular bone, arrow points to traces of live bone marrow. Magnifications of $4 \mathrm{x}(\mathrm{A}, \mathrm{C}$, and D) and of $40 \mathrm{X}(\mathrm{B})$.

\section{Discussion}

Sheep were used in this experiment because of their similar hip anatomy to humans, and because of their size which allows perform surgical procedures used in humans ${ }^{25}$. These features make the sheep a good model for studies in orthopedic surgery.

Six weeks after ethanol injection in femoral head of the ovines through the core decompression technique Manggold et al. ${ }^{8}$ found most severely damaged areas in the femoral head, and bone regeneration occurred in twelve weeks after induction. Therefore, we chose perform the transplantation of stem cells six weeks after ONFH induction, and evaluate the cell therapy result 10 weeks after induction.

The main objective of the treatment in ONFH is to preserve the hip joint. Stem cell therapy in ONFH could be a helpful tool in this disease, avoiding the progression of injury, and representing a possible cure. According Caplan ${ }^{26}$, adult stem cells provide replacement and repair descendants for normal turnover or injured tissues. These cells have been isolated and expanded in culture, and their use for therapeutic strategies requires 
technologies not yet perfected. This article provides more information about mesenchymal stem cell therapy, and behavior of transplanted cells in site of injury.

Stem cells from human dental pulp are the new promise of cell therapy. These cells were isolated, cultured and extensively characterized by Kerkis et al. ${ }^{20}$. However, few clinical trials have been performed with these cells in the field of cell therapy and tissue engineering. In this study, hIDPSC were applied in an animal model, providing more information about safe and the efficacy of these cells.

Although some relevant clinical data on cellular therapy

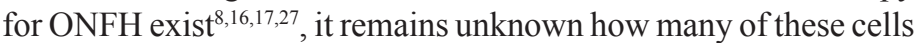
actually participate in the bone reparation and engraftment process and how many survive and proliferate in the center of the femoral head, after the transplant. This observation has also been made by others ${ }^{18}$. For stem cell therapy we choose to used oMSC and LacZ-oMSC due to small number of transduced cells obtained after the procedures for viral transduction. Despite the small amount of LacZ-oMSC injected, the X-Gal staining was positive in all gross slices of femoral head in $\mathrm{CD}+\mathrm{oMSC}$ group. We cannot say precisely how many cells proliferated but the fact that we were able to macroscopically detect the $\beta$-galactosidase expression four weeks after the transplant of LacZ-oMSCs, indicates that great cell proliferation had occurred.

The methods used to tracking modified MSC in a bone defect did have obtained limited success, mainly because the label was not compatible with the specifics procedures used for bone histology ${ }^{19}$.In this study the bone samples used for evaluate $\mathrm{CD}+\mathrm{oMSC}$ group were lost in procedures cause by bone histology preparation. However, the macroscopic findings after $\mathrm{X}$-Gal staining gave us positive results, confirming the success of transplant.

The studies performed by Hernigou et al. ${ }^{15}$ done in patients with ONFH have shown that the level of activity and the number of mesenchymal cells inside the stromal and hematopoietic compartments of the bone marrow are depressed in these patients. Gangji et al. ${ }^{16,17,27}$ used in their experiments eighteen patients with ONFH, and treated then with core decompression alone, and core decompression associated with bone marrow mononuclear cells. A follow up of five years showed that only one of ten patients, in the experimental group, have need of a total hip replacement after the therapy, and four of eight patients in the control group underwent prosthetic surgery. These data leave us to believe that mesenchymal stem cell therapy is a promising treatment on ONFH. Thus it seems appropriate that a treatment performed with purified mesenchymal stem cells and would be more effective than using a pool of mononuclear cells. In our study we used expanded in culture mesenchymal stem cells for two sources, instead of simple pool fresh extract from patient.

A case report done by Kim et al. ${ }^{27}$ showed a 31 years old patient with bilateral ONFH that was submitted a core decompression with allograft implant in left femoral head, while the right side was treated by injection of autologous cultured osteoblasts for four weeks after the core decompression. The author concludes that despite using only a patient, cultured osteoblasts appear to be effective for treatment. Bone is a living organ. Mesenchymal stem cells can differentiate into different cell types, such as bone, cartilage, fat and vessels. For this reason, we believe that a mesenchymal stem cell therapy is more appropriate than the use of cultured osteoblasts, because these cells can give rise to all cell types found in bone tissue.

In Brazil, Daltron et al. ${ }^{28}$ performed the treatment of ONFH with mononuclear bone marrow cells in sickle cell disease in eight patients. After eigth months, seven of the eight patients reported improvement from symptoms. The authors consider that the interpretation or these early results is limited due to the small sample and to the short duration of follow-up. We consider the same. The small number of animals in our research is due to the high cost of animals and their maintenance. A follow-up in ovine model of ONFH is not possible because the injury induced presents spontaneous resolution. Our data are in accordance to previous studies, which successfully applied the central decompression technique associated with autologous bone marrow cells in humans $s^{17,28}$. We also showed that the procedure performed in this study is safe and does not lead to bone fractures or to the appearance of tumors, and that the cells used for treatment are still alive weeks after the procedure.

\section{Conclusions}

Our findings show that the MSC injected in the femoral head were able to engraftment in the bone tissue. In contrast the histological data of human immature dental-pulp stem cells transplanted suggested that the bone regeneration in animals was faster than that observed in animals submitted to central decompression alone. Furthermore Our preliminary data demonstrated that ovine model of osteonecrosis of femoral head can be successfully used in comparative studies of animal and human stem cell transplantation aiming at reconstruction of bone tissue injury.

\section{References}

1. Magnussen RA, Guilak F, Vail TP. Articular cartilage degeneration in post-collapse osteonecrosis of the femoral head - radiographic staging, macroscopic grading, and histologic changes. J Bone Joint Surg Am. 2005;87:1272-7.

2. Wang CJ, Wang FS, Huang CC, Yang KD, Weng LH, Huang HY. Treatment for osteonecrosis of the femoral head: Comparison of extracorporeal shock waves with core decompression and bone-grafting. J Bone Joint Surg Am. 2005;87:2380-7.

3 . Ficat RP. Idiopathic bone necrosis of the femoral-head - early diagnosis and treatment. J Bone Joint Surg Br. 1985;67:3-9.

4. Gangji V, Toungouz M, Hauzeur JP. Stem cell therapy for osteonecrosis of the femoral head. Expert Opin Biol Ther. 2005;5:437-42.

5. Marciniak D, Furey C, Shaffer JW. Osteonecrosis of the femoral head - a study of 101 hips treated with vascularized fibular grafting. J Bone Joint Surg Am. 2005;87:742-7.

6. Boss JH, Misselevich I. Osteonecrosis of the femoral head of laboratory animals: the lessons learned from a comparative study of osteonecrosis in man and experimental animals. Vet Pathol. 2003;40:345-54.

7. Yoon TR, Song EK, Rowe SM, Park CH. Failure after core decompression in osteonecrosis of the femoral head. Int Orthop. 2001;24:316-8.

8. Abou-Jamra RC, Valente PR, Araújo A, Oliveira RCS, Saldiva PH, Pedreira DAL. Simplified correction of a meningomyelocele-like defect in the ovine fetus. Acta Cir Bras. 2009;24:239-44. 
9. Oliveira RCS, Valente PR, Abou-Jamra RC, Araújo A, Saldiva PH, Pedreira DAL. Biosynthetic cellulose induces the formation of a neoduramater following pre-natal correction of meningomyelocele in fetal sheep. Acta Cir Bras. 2007;22:174-81.

10. Pedreira DAL, Oliveira RCS, Valente PR, Abou-Jamra RC, Araújo A, Saldiva PH. Validation of the ovine fetus as an experimental model for the human myelomeningocele defect. Acta Cir Bras. 2007;22:168-73.

11. Cerqueira A, Silveira RL, Oliveira MG, Filho MS, Heitz C. Bone tissue microscopic findings related to the use of diode laser $(830 \mathrm{~nm})$ in ovine mandible submitted to distraction osteogenesis. Acta Cir Bras. 2007;22:92-7. 12. Manggold J, Sergi C, Becker K, Lukoschek M, Simank HG. A new animal model of femoral head necrosis induced by intraosseous injection of ethanol. Lab Anim. 2002;36:173-80.

13. Prockop DJ. Marrow stromal cells as steam cells for nonhematopoietic tissues. Science. 1997;276:71-4.

14. D'aquino R, Papaccio G, Laino G, Graziano A. Dental pulp stem cells: a promising tool for bone regeneration. Stem Cell Rev. 2008;4:21-6.

15. Hernigou P, Beaujean F, Lambotte JC. Decrease in the mesenchymal stem-cell pool in the proximal femur in corticosteroid-induced osteonecrosis. J Bone Joint Surg Br. 1999;81:349-55.

16. Gangji V, Hauzeur JP, Matos C, De Maertelaer V, Toungouz M, Lambermont M. Treatment of osteonecrosis of the femoral head with implantation of autologous bone-marrow cells - a pilot study. J Bone Joint Surg Am. 2004;86:1153-60.

17. Gangji V, Toungouz M, Lambermont M, Bastianelli E, Hauzeur J. Treatment of osteonecrosis of the femoral head with implantation of autologous bone-marrow cells: five-year follow-up. Bone. 2007;40:46-7. 18. Hassan HT, El-Sheemy M. Adult bone-marrow stem cells and their potential in medicine. J R Soc Med. 2004;97:465-71.

19. Hannouche D, Raould A, Nizard RS, Sedel L, Petite H. Embedding of bone samples in methylmethacrylate: a suitable method for tracking lacz mesenchymal stem cells in skeletal tissues. J Histochem Cytochem. 2007;55:255-62.

20. Kerkis I, Kerkis A, Dozortsev D, Stukart-Parsons GC, Massironi SMG, Pereira LV, Caplan AI, Cerruti HF. Isolation and characterization of a population of immature dental pulp stem cells expressing oct- 4 and other embryonic stem cell markers. Cells Tissues Organs. 2006;184:105-16.

21. Kerkis I, Ambrósio CE, Kerkis A, Martins DS, Zucconi E, Fonseca SAS, Cabral RM, Maranduba CMC, Gaiad TP, Morini AC, Vieira NM, Brólio MP, Sant'anna OA, Miglino MA, Zatz M. Early transplantation of human immature dental pulp stem cells from baby teeth to golden retriever muscular dystrophy (GRMD) dogs: local or systemic? J Transl Med. 2008;6:35.

22. Siqueira da Fonseca SA, Abdelmassih S, de Mello Cintra Lavagnolli T, Serafim RC, Clemente Santos EJ, Mota Mendes C, de Souza Pereira V, Ambrosio CE, Miglino MA, Visintin JA, Abdelmassih R, Kerkis A, Kerkis I. Human immature dental pulp stem cells' contribution to developing mouse embryos: production of human/mouse preterm chimaeras. Cell Prolif. 2009;42:132-40.

23 Monteiro BG, Serafim RC, Melo GB, Silva MCP, Lizier NF, Maranduba CMC, Smith RL, Kerkis A, Cerruti H, Gomes JAP, Kerkis I. Human immature dental pulp stem cells share key characteristic features with limbal stem cells. Cell Prolif. 2009;42:587-94.

24. Gomes JAP, Monteiro BG, Melo GB, Smith RL, da Silva MCP, Lizier NF, Kerkis A, Cerruti H, Kerkis I. Corneal reconstruction with tissue-engineered cell sheets composed of human immature dental pulp stem cells. Invest Ophthalmol Vis Sci. 2009;51:1408-14.

25. Kirker-Head CA, Gerhart TN, Armstrong R, Schelling SH, Carmel LA. Healing bone using recombinant human bone morphogenetic protein 2 and copolymer. Clin Orthop Relat Res. 1998;(349):205-17.

26. Caplan AI. Mesenchymal stem cells: cell-based reconstructive therapy in orthopedics. Tissue Eng. 2005;11:1198-211.

27. Kim SK, Bahk WJ, Chang CH, Jang JD, Shul KH. Treatment of osteonecrosis of the femoral head using autologous cultured osteoblasts: a case report. J Med Case Reports. 2008;2:58.

28. Daltro GC, Fortuna VA, Araújo MAS, Lessa PIF, Sobrinho UAB, Borejevic R. Tratamento da osteonecrose da cabeça femoral com células progenitoras autólogas em anemia falciforme. Acta Ortop Bras. 2008;16:23-7.

\section{Acknowledgments}

We would like to thank FAPESP/CNPq for providing the necessary funds and the fellowships for this study. We also would like to thank the Post-graduate Program of the Anatomy in Domestic and Wild Animals from Faculty of Veterinary Medicine and Animal Science, São Paulo University (FMVZ-USP) and National Institute of Science and Technology in Stem Cells and Cell Therapy (INCTC).

\section{Correspondence:}

Matheus Levi Tajra Feitosa

Cid. Univ. Armando de Salles Oliveira

Setor de Anatomia

Av.Prof. Dr. Orlando Marques de Paiva, 87

05508-000 São Paulo - SP Brasil

Phone: (55 11)3091-7805

mtajra@gmail.com

Received: February 09, 2010

Review: April 12, 2010

Accepted: May 18, 2010

\section{How to cite this article}

Feitosa MLT, Fadel L, Beltrão-Braga PCB, Wenceslau CV, Kerkis I, Kerkis A, Birgel-Júnior EH, Martins JFP, Martins DS, Miglino MA, Ambrósio CE. Successful transplant of mesenchymal stem cells in induced osteonecrosis of the ovine femoral head. Preliminary results. Acta Cir Bras. [serial on the Internet] 2010 Sept-Oct;25(5). Available from URL: http://www.scielo.br/acb 